\title{
Development of inattention, impulsivity, and processing speed as measured by the d2 Test: Results of a large cross-sectional study in children aged 7-13
}

Citation for published version (APA):

Wassenberg, R., Hendriksen, J. G. M., Hurks, P. P. M., Feron, F. J. M., Keulers, E. H. H., Vles, J. S. H., \& Jolles, J. (2008). Development of inattention, impulsivity, and processing speed as measured by the d2 Test: Results of a large cross-sectional study in children aged 7-13. Child Neuropsychology, 14(3), 195210. https://doi.org/10.1080/09297040601187940

Document status and date:

Published: 01/01/2008

DOI:

$10.1080 / 09297040601187940$

Document Version:

Publisher's PDF, also known as Version of record

\section{Please check the document version of this publication:}

- A submitted manuscript is the version of the article upon submission and before peer-review. There can be important differences between the submitted version and the official published version of record. People interested in the research are advised to contact the author for the final version of the publication, or visit the DOI to the publisher's website.

- The final author version and the galley proof are versions of the publication after peer review.

- The final published version features the final layout of the paper including the volume, issue and page numbers.

Link to publication

\footnotetext{
General rights rights.

- You may freely distribute the URL identifying the publication in the public portal. please follow below link for the End User Agreement:

www.umlib.nl/taverne-license

Take down policy

If you believe that this document breaches copyright please contact us at:

repository@maastrichtuniversity.nl

providing details and we will investigate your claim.
}

Copyright and moral rights for the publications made accessible in the public portal are retained by the authors and/or other copyright owners and it is a condition of accessing publications that users recognise and abide by the legal requirements associated with these

- Users may download and print one copy of any publication from the public portal for the purpose of private study or research.

- You may not further distribute the material or use it for any profit-making activity or commercial gain

If the publication is distributed under the terms of Article $25 \mathrm{fa}$ of the Dutch Copyright Act, indicated by the "Taverne" license above, 


\title{
DEVELOPMENT OF INATTENTION, IMPULSIVITY, AND PROCESSING SPEED AS MEASURED BY THE d2 TEST: RESULTS OF A LARGE CROSS-SECTIONAL STUDY IN CHILDREN AGED 7-13
}

\author{
Renske Wassenberg, ${ }^{1}$ Jos G. M. Hendriksen, ${ }^{1,2}$ \\ Petra P. M. Hurks, ${ }^{1,3}$ Frans J. M. Feron, ${ }^{4}$ \\ Esther H. H. Keulers, ${ }^{1}$ Johan S. H. Vles, ${ }^{5}$ and Jelle Jolles ${ }^{1}$ \\ ${ }^{1}$ Department of Psychiatry and Neuropsychology, Maastricht University, The \\ Netherlands, ${ }^{2}$ Childhood Rehabilitation Center Franciscusoord, Valkenburg, The \\ Netherlands, ${ }^{3}$ Department of Psychology, Maastricht University, The Netherlands, \\ ${ }^{4}$ Youth Health Care Division of the Regional Public Health Institute Maastricht, The \\ Netherlands, ${ }^{5}$ Department of Neurology, University Hospital Maastricht, Maastricht, \\ The Netherlands
}

The development of three aspects of selective attention was studied in 451 Dutch schoolchildren attending second to sixth grade. Selective attention was measured with the d2 Test of attention. The largest age differences were found for processing speed that continued to improve until the sixth grade. Impulsivity, as measured by the percentage of errors of commission, decreased until the fourth grade. Inattention, measured by the percentage of errors of omission, was stable in all grades. Processing speed and impulsivity were correlated with the score on the Attention Problems subscale of the Child Behavior Checklist. These results imply that selective attention continues to develop, at least, until the end of elementary school. The findings are support for a step-wise model of cognitive development (P. Anderson, 2002).

Keywords: Selective attention; Cognitive development; Interindividual variance.

Attentional processes are important for normal functioning in daily life. An adequate attention is a prerequisite for normal performance on the majority of neuropsychological tests (Cooley \& Morris, 1990). Recently, investigators became interested in how different aspects of attention develop in children, both in normally developing children (Klenberg, Korkman, \& Lahti-Nuuttila, 2001; Klimkeit, Mattingley, Sheppard, Farrow, \& Bradshaw, 2004; Lin, Hsiao, \& Chen, 1999; McKay, Halperin, Schwartz, \& Sharma, 1994; Rebok et al., 1997; Ruff \& Lawson, 1990; Stahl \& Pry, 2005) and in children with developmental disorders, such as attention deficit/hyperactivity disorder (ADHD; Brodeur \& Pond, 2001; Drechsler, Brandeis, Földényi, Imhof, \& Steinhausen, 2005; Marakovitz \&

We are grateful to Frouke Sondeijker, and to the board, teachers, parents, and children of primary schools: "de Cramignon" in Eijsden, and "Scharn" in Maastricht, the Netherlands, for their kind cooperation.

Address correspondence to Renske Wassenberg, Department of Psychiatry and Neuropsychology, Maastricht University, P.O. Box 616, 6200, MD Maastricht, The Netherlands. E-mail: r.wassenberg@np.unimaas.nl 
Campbell, 1998). The main conclusion of these studies was that attentional functioning develops in spurts throughout childhood and adolescence. This development seems to parallel the growth spurts in the maturation of the brain, particulary of specific areas in the prefrontal cortex (Gogtay, Giedd, Lusk, et al., 2004; Klingberg, Vaidya, Gabrieli, Moseley, \& Hedehus, 1999; Sowell \& Jernigan, 1998; Thatcher, 1991). A recent model placed this differential cognitive development in a theoretical framework (P. Anderson, 2002). The present study focused on selective attention, the ability to attend to relevant stimuli and to ignore irrelevant stimuli (Baron, 2004; R. A. Cohen, 1993; Tannock, 2003). It is critical for the majority of other cognitive processes because it is needed for selecting incoming sensory information, encoding information in memory, retaining and manipulating information into working memory, and successfully executing goaldirected behavior (Smith \& Jonides, 1999). Based on the model named above (P. Anderson, 2002), we investigated the differential development of subprocesses within selective attention.

Previous studies of the development of selective attention across childhood yielded inconsistent results as to the age until most improvement occurs. McKay and colleagues (1994) did not find differences in performance between children aged 7 to 11 years $(n=62)$ and adults $(n=16$, aged 21 to 48 years), whereas Brodeur and Pond (2001) reported better performance in 9- to 11-year-old children $(n=18)$ than in 6- to 8 -year-old children $(n=14)$. Rebok and colleagues (1997) found a significant improvement from 8 to 10 years $(n=289)$. Klimkeit and colleagues (2004) found the largest improvement between the ages of 8 and 10 years, with a plateau in performance between 10 and 12 years of age $(n=40)$. Klenberg and colleagues (2001) also reported that development was complete by 10 years $(n=400)$. In summary, selective attention appears to be fully developed by about 10 years of age.

However, selective attention encompasses different processes, such as speed and accuracy (Manly et al., 2001). These processes may have distinct developmental patterns and they have not been examined by all of the above mentioned studies. Interestingly, McKay and colleagues (1994), who failed to detect group differences in selective attention, used speed as the sole outcome measure. Brodeur and Pond (2001) and Rebok and colleagues (1997) reported on both speed and accuracy, whereas Klenberg and colleagues (2001) used a speed-accuracy trade-off as the dependent measure. In contrast, Klimkeit and colleagues (2004) used four types of errors besides speed, among others misses and premature responses. In the present study of how selective attention develops with age in schoolchildren in the second to sixth grades of regular primary school, we adopted a similar approach. Three aspects of selective attention were studied, namely processing speed (number of items processed), impulsivity (percentage of errors of commission), and inattention (percentage of errors of omission). We expected performance on these aspects to be optimal by the fourth grade, when children are about 10 years, based on the results of the above described studies (Brodeur \& Pond, 2001; Klenberg et al., 2001; Klimkeit et al., 2004; McKay et al., 1994; Rebok et al., 1997).

We used the d2 Test of attention to measure the different aspects of selective attention (Baron, 2004; Brickenkamp \& Zillmer, 1998; Culbertson \& Sari, 1997). Mental concentration, visual perception, visual scanning ability, and perceptual speed are thought to be involved in this well-known test that takes 6 minutes to administer (Baron, 2004; Brickenkamp \& Zillmer, 1998). Although the $\mathrm{d} 2$ Test has been described as a test of both selective and sustained attention (Baron, 2004), the duration of 4 minutes and 40 seconds required for the test after practice and instruction does not approach that of classic 
vigilance or sustained-attention tasks. For example, continuous performance tests usually last about 14 minutes (Baron, 2004; Lezak, Howieson, \& Loring, 2004; Spreen \& Strauss, 1998). Also, the prompt that is given every 20 seconds makes this test dissimilar to classic tests of sustained attention, in which performance is self-monitored (Brickenkamp \& Zillmer, 1998). For these reasons, the d2 Test should be considered primarily a test of selective attention.

The $\mathrm{d} 2$ Test has the advantage over other tests of selective attention that it is short, can be easily administered, does not require extensive instruction, can be administred to a large age-range and to groups or individuals alike, and it has good psychometric properties (Brickenkamp \& Zillmer, 1998; Culbertson \& Sari, 1997; Culbertson \& Zillmer, 1998; Eser, 1987). It has been used in various European and North American studies (Lufi, 2001; Muller et al., 2003; Olvera, Semrud-Clikeman, Pliszka, \& O’Donnell, 2005; Reimann et al., 2000; Seidl, Peyrl, Nicham, \& Hauser, 2000). We do not know of previous studies that investigated the development of selective attention using the $\mathrm{d} 2$ Test. However, the $\mathrm{d} 2$ Test is commonly used in neuropsychological studies of children, among others in studies of the effect of neurofeedback treatment for ADHD (Fuchs, Birbaumer, Lutzenberger, Gruzelier, \& Kaiser, 2003), the neuropsychological markers of schizophrenia in adolescents (Klemm, Schmidt, Knappe, \& Blanz, 2006; Schreiber, Stolz-Born, Heinrich, Kornhuber, \& Born, 1992), the neuropsychological effects of irradiation for childhood leukemia (Langer et al., 2002), the remediation of attention deficits (Penkman, 2004), the neuropsychological profiles of children and adolescents with temporal lobe epilepsy (Lendt, Helmstaedter, \& Elger, 1999), the neuropsychological profiles of early treated children with phenylketonuria (Weglage et al., 1999; Weglage, Pietsch, Funders, Koch, \& Ullrich, 1996), and the influence of methylphenidate on cortical processing of children with ADHD (Wienbruch, Paul, Bauer, \& Kivelitz, 2005). Because children who have not learned the difference between the characters " $d$ " and "p" cannot be tested with the $\mathrm{d} 2$ Test (Brickenkamp \& Zillmer, 1998), we chose to study children in the second (age 7) and higher grades of school in order to be certain that they had sufficient knowledge of the characters used.

A child's development is affected by several age-extrinsic factors. For example, parental education and occupation have a large impact on problem behavior and attention problems in 5- to 6-year-old children (Kalff, Kroes, Vles, Bosma, et al., 2001), as does living in a deprived environment (Kalff, Kroes, Vles, Hendriksen, et al., 2001). Factors such as parental level of education have received little attention in previous studies of selective attention in children (Brodeur \& Pond, 2001; Drechsler et al., 2005; Klimkeit et al., 2004; McKay et al., 1994), but could be confounders (Bradley \& Corwyn, 2002; Jackson, 2003). We therefore included three age-extrinsic factors: parental level of education, verbal intelligence, and attention problems in daily life. The selection of this last factor allowed us to study the practical implications and ecological validity of the $\mathrm{d} 2$ Test. Attention problems in daily life were measured with the Attention Problems scale of the Child Behavior Checklist (CBCL; Achenbach, 1991; translated into Dutch by Verhulst, van der Ende, \& Koot, 1996).

In summary, the aims of this study were to investigate age differences in processing speed, inattention, and impulsivity in a large sample of healthy Dutch schoolchildren attending the second to the sixth grade and to study the influence of parental level of education, verbal ability, and attention problems in daily life on this development. We expected to find no further improvement for the different aspects of selective attention after the age of 10 years. 


\section{METHOD}

\section{Procedure and Participants}

The sampling frame consisted of all children attending the second through sixth grades of two regular elementary schools in south Limburg, an area in the south of the Netherlands (250,000 inhabitants). These schools were selected in cooperation with the Youth Health Care (YHC) Division of the Regional Public Health Institute Maastricht, The Netherlands. All parents $(N=561)$ were sent a letter describing the purpose of the study and were asked to cooperate. Four hundred and eighty-eight parent-pairs $(87.0 \%)$ replied: 465 of them gave permission for the investigation and signed an informed consent (82.9\%) and 23 did not (4.1\%); 73 did not reply (13.0\%).

Information about the parents who did not give permission or did not respond was obtained anonymously from YHC records, which is permitted by law. There were no significant differences with regard to age and sex between the parents who did not wish to cooperate, those that did not reply, and randomly selected parents whose child participated in the study. However, the nonresponding parents had a lower level of educational attainment than the other parents $(M=1.49$ vs. $1.70, t=2.53, p=.013)$.

Nine children were ill on the day the investigation was scheduled, so 456 children participated in the study $(81.3 \%)$. Parents who agreed to cooperate completed a short questionnaire on their education and occupation, the presence of learning and/or behavior problems in their child, and the attention problems subscale of the CBCL (Achenbach, 1991; Verhulst, van de Ende, \& Koot, 1996). The CBCL is a screening instrument for behavior problems in children and is completed by parents. The attention subscale includes 11 items. Each item can be scored as 0 (this problem is not present), 1 (this problem is sometimes present), or 2 (this problem is always present). The attention problems raw score was used as the outcome variable (maximum possible $=22$ ). The presence of attention problems did not differ between the grades $(F[4,436]=.94, p=.441)$.

The data of two children who were previously diagnosed with ADHD by health care professionals (not based on this investigation) were excluded from the analyses. This low number of children with ADHD is not representative of the normal Dutch population as the prevalence is estimated to be $3.8 \%$ (Kroes et al., 2001). This distinction is probably due to the fact that we told the schools and parents we wanted to recruit normally developing children for the study. This may have led parents of children with ADHD to give no permission or to refrain from responding at all. Secondly, and possibly more importantly, Dutch children with ADHD are often placed at a school for children with special needs. Thus, the prevalence of ADHD at regular elementary schools is lower than in the total population, as children with ADHD aged 7 and higher may have already been placed at a special needs school. Two children had been diagnosed with dyslexia. Because the results of the study did not change when these children were excluded, their data was retained. The data of three other children were not analyzed because these children had completed the $\mathrm{d} 2$ Test with the sheet upside down, and as a result had marked the wrong targets (all p's with two dashes). The remaining 451 children ( 243 boys [54\%] and 208 girls [46\%]) were aged 7.42 to 13.00 years.

Level of parental education was based on the partner with the highest level of education (Kalff, Kroes, Vles, Bosma, et al., 2001). The majority of participants came from middle to highly educated families: 12 parent-pairs $(2.7 \%)$ had a low level of parental education, 139 parent-pairs $(30.8 \%)$ a middle level, and 286 parent-pairs (63.4\%) a high level; relevant data for 14 parent-pairs were missing (Directoraat-Generaal voor de 
Arbeidsvoorziening, 1989). Because only a few parent-pairs had a low level of education, level of parental education was scored on a 2-point scale low/middle (1 point, primary school to vocational education degree) vs. high (general secondary education to doctoral degree $)$. Level of parental education did not differ between the grades $(F[4,432]=.92$, $p=.452$ ). Table 1 shows the characteristics of the participants and their parents.

Children took tests of selective attention, verbal ability, and sense of time (reported on in a separate paper, Wassenberg et al., 2007) in their classroom. Testing took 30-45 minutes; all tests were administered in the same order to all children. The $\mathrm{d} 2 \mathrm{Test}$ was administered first to minimize effects of fatigue. Children whose parents had not agreed to their participation in the study were either present in the classroom during the study (working on their own) or left the room with their teacher or a teaching assistant. The tests were administered by a psychologist and psychology graduate who had been trained in test administration. They were not aware of the specific hypotheses of the study. The ethics commission of the Faculty of Psychology, University of Maastricht, approved the study.

\section{Instruments}

Selective attention was measured with the $d 2$ Test of attention (Brickenkamp \& Zillmer, 1998; Culbertson \& Sari, 1997). The d2 Test consists of 14 lines, each containing 47 characters; in total there are 658 items. The test items are composed of the characters "p" and "d" with one to four dashes, arranged either individually or in pairs above and below the character. The subject is required to scan across the line to identify and to mark all "d's" with two dashes, which can be either above or below the letter. Twenty seconds per line are allowed, after which the subject is told to continue to the next line by the

Table 1 Demographic Characteristics of the Participants.

\begin{tabular}{|c|c|c|c|c|c|c|c|}
\hline \multirow[b]{2}{*}{ Characteristic } & & \multicolumn{5}{|c|}{ Grade } & \multirow[b]{2}{*}{ Difference $^{1}$} \\
\hline & & $2(n=82)$ & $3(n=86)$ & $4(n=102)$ & $5(n=92)$ & $6(n=89)$ & \\
\hline \multirow[t]{2}{*}{$n$} & Boys & $41(50 \%)$ & $51(59.3 \%)$ & $58(56.9 \%)$ & $44(47.8 \%)$ & $49(55.1 \%)$ & \multirow{2}{*}{ NS } \\
\hline & Girls & $41(50 \%)$ & $35(40.7 \%)$ & $44(43.1 \%)$ & $48(52.2 \%)$ & $40(44.9 \%)$ & \\
\hline Age & $\begin{array}{l}\text { Mean } \\
(S D)\end{array}$ & $\begin{array}{l}8.06 \\
(.36)\end{array}$ & $\begin{array}{l}8.99 \\
(.43)\end{array}$ & $\begin{array}{c}10.13 \\
(.41)\end{array}$ & $\begin{array}{r}11.07 \\
(.41)\end{array}$ & $\begin{array}{c}12.09 \\
(.40)\end{array}$ & $2<3<4<5<6$ \\
\hline EVA & $\begin{array}{l}\text { Mean } \\
(S D)\end{array}$ & $\begin{array}{l}39.89 \\
(4.25)\end{array}$ & $\begin{array}{l}44.72 \\
(4.03)\end{array}$ & $\begin{array}{l}47.64 \\
(4.05)\end{array}$ & $\begin{array}{l}51.52 \\
(3.25)\end{array}$ & $\begin{array}{l}52.88 \\
(3.83)\end{array}$ & $2<3<4<5<6$ \\
\hline \multirow[t]{3}{*}{ LPE } & $\mathrm{L} / \mathrm{M}^{3}$ & $25(30.5 \%)$ & $33(38.4 \%)$ & $39(38.2 \%)$ & $29(31.5 \%)$ & $25(28.1 \%)$ & \multirow{3}{*}{ NS } \\
\hline & High & $56(68.3 \%)$ & $52(60.5 \%)$ & $58(56.9 \%)$ & $60(65.2 \%)$ & $60(67.4 \%)$ & \\
\hline & Mis & $1(1.2 \%)$ & $1(1.2 \%)$ & $5(4.9 \%)$ & $3(3.3 \%)$ & $4(4.5 \%)$ & \\
\hline AT & $\begin{array}{l}\text { Mean } \\
(S D)\end{array}$ & $\begin{array}{l}1.54 \\
(1.55)\end{array}$ & $\begin{array}{l}1.86 \\
(2.23)\end{array}$ & $\begin{array}{l}2.15 \\
(2.41)\end{array}$ & $\begin{array}{c}1.76 \\
(2.38)\end{array}$ & $\begin{array}{l}1.73 \\
(2.29)\end{array}$ & NS \\
\hline
\end{tabular}

Note. EVA = Estimate of Verbal Ability, mean and $S D$ of the raw score on the Vocabulary subtest of the RAKIT, maximum possible $=60$ (Bleichrodt et al., 1987; Evers et al., 2000); LPE = Level of Parental Education (Directoraat-Generaal voor de Arbeidsvoorziening, 1989), number of children in each category, L/M = Low/ Middle level of parental education; High $=$ High level of parental education, Mis = Missing data; $\mathrm{AT}=$ mean and $S D$ of the raw score on the attention problems subscale of the CBCL, maximum possible $=22$ (Achenbach, 1991; Verhulst et al., 1996).

${ }^{1}$ Differences between grades, calculated by one-way ANOVA with post hoc Bonferroni multiple comparisons, $2=2^{\text {nd }}$ grade, $3=3^{\text {rd }}$ grade, $4=4^{\text {th }}$ grade, $5=5^{\text {th }}$ grade, $6=6^{\text {th }}$ grade . 
words "stop, next line." The subject is asked to work as quickly as possible without making mistakes. The $\mathrm{d} 2$ Test can be administered individually or in group format; in the present study the latter format was chosen. Total administration time for the $\mathrm{d} 2$ Test is 6 minutes. The reliability and validity of the d 2 Test are reported to be good. More specifically, internal consistency of the total number of items processed ranged from .84 to .98 in different studies, test-retest reliability was .87 in a group of students that were retested after 6 months, and construct validity was supported in a factor analytic study in which the d2 Test loaded with other tests of selective attention such as the Stroop Color Word Test and the Symbol Digit Modalities Test (Brickenkamp \& Zillmer, 1998). Reliability and validity have also been established in studies with children: internal consistency of the total number of items processed was .93 in a study of 9- to 16-year-old German children with deviant behavior (Eser, 1987); test-retest reliability was .75 in 18 German adolescents with behavior problems when they were retested after 4 months (Eser, 1987), and significant correlations of medium to high effect size were found between $\mathrm{d} 2$ Test and Tower of London performance in a study of American children with ADHD (Culbertson \& Zillmer, 1998).

The three outcome measures used in this study were (1) the total number of items processed, as a measure of processing; (2) the number of misses (errors of omission: d's with two dashes that were not marked) divided by processing speed as a measure of inattention, and (3) the number of false alarms (errors of commission: marked d's with less or more than 2 dashes or p's) divided by processing speed as a measure of impulsivity speed (see d2 Test manual; Brickenkamp \& Zillmer, 1998).

Verbal ability (EVA) was estimated with the Picture Vocabulary subtest of the Revised Amsterdam Child Intelligence Test for children aged 4 years and 2 months to 11 years and 1 month (Bleichrodt, Drenth, Zaal, \& Resing, 1987; Evers, van Vliet-Mulder, \& Groot, 2000). The Picture Vocabulary test closely resembles the Peabody Picture Vocabulary test (Dunn, Dunn, Robertson, \& Eisenberg, 1979), a commonly used instrument to estimate verbal intelligence (Marakovitz \& Campbell, 1998). During the Picture Vocabulary test, the child has to choose one of four pictures that matches the word the experimenter reads aloud. These words increase in complexity. For the present study, the booklet version of the Picture Vocabulary test was adapted for use in class, by copying the pictures on sheets and projecting them onto a white screen. Every child marked his/her answers on an answer form showing small versions of the same pictures projected on the white screen. Because some subjects were older than the available norms for the test, the outcome variable was the total number of correctly chosen pictures (maximum possible $=60$ ). As can be expected, performance improved linearly with school grade (see Table 1).

\section{Statistical Analyses}

The statistical package SPSS 11.5 was used for all analyses. Specific group differences on $\mathrm{d} 2$ Test processing speed were analyzed with four separate linear regression analyses. In these analyses, one of the grades was systematically compared with the others. This was done by including one of four sets of dummy variables. For example, with the dummy variables of the second grade, the following comparisons were made: second with third grade, second with fourth grade, second with fifth grade, and second with sixth grade. No set of dummy variables was needed for the highest grade, because all comparisons had been made already. The second block of linear regression analyses included the same grade differences as in block 1 but also parental level of education (coded as: 
low/middle $=1$, high $=2$ ), estimate of verbal ability (continuous), CBCL attention problems scale raw score (continuous), and sex (to control for possible differences, coded as: boy $=1$, girl $=2$ ).

To analyze impulsivity and inattention, we first visually inspected the distribution of these variables, to check for normality (see Figures 1A and B). As can be seen in Figure 1, relatively few impulsive errors were made, whereas inattentive errors were more common. Neither of the two measures was distributed normally. Thus, the two variables could not be analyzed continuously. The cutoff points between "normal" and "weak" was placed at $3.0 \%$ for inattention, and at $1.0 \%$ for impulsivity, because at these points the curves started to bend (see arrows in Figures 1A and B). Using these cutoff points, $27.1 \%$ of the participants showed weak inattention and $31.3 \%$ showed weak impulsivity. More conservative cutoff points were considered, but these made the groups of children who were

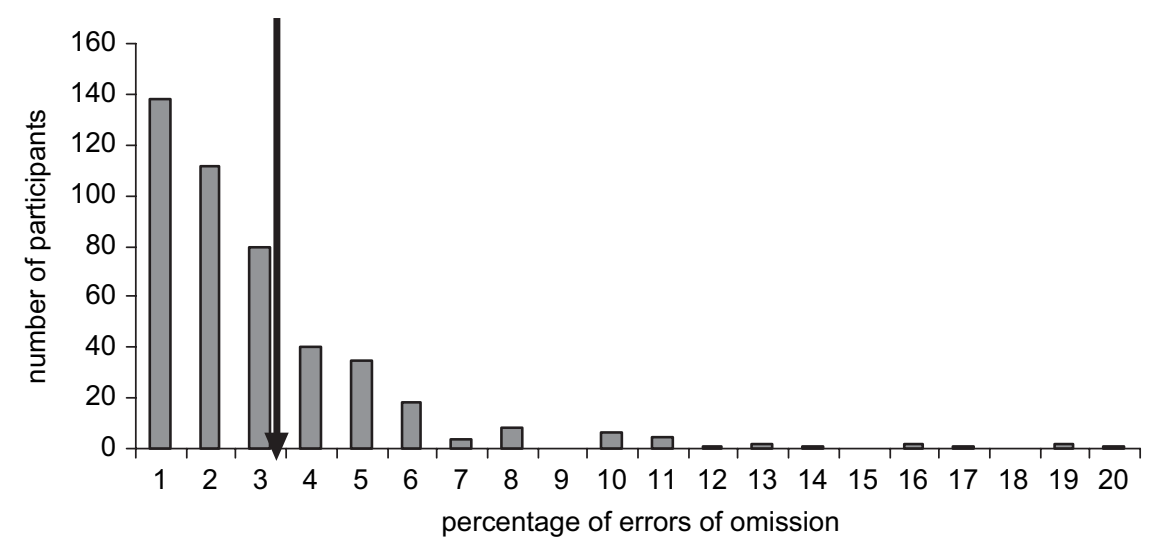

Figure 1A Distribution of inattention.

Note: Number of errors of omission divided by total number of items processed. The arrow indicates the borderline $(3 \%)$ between normal and weak performance.

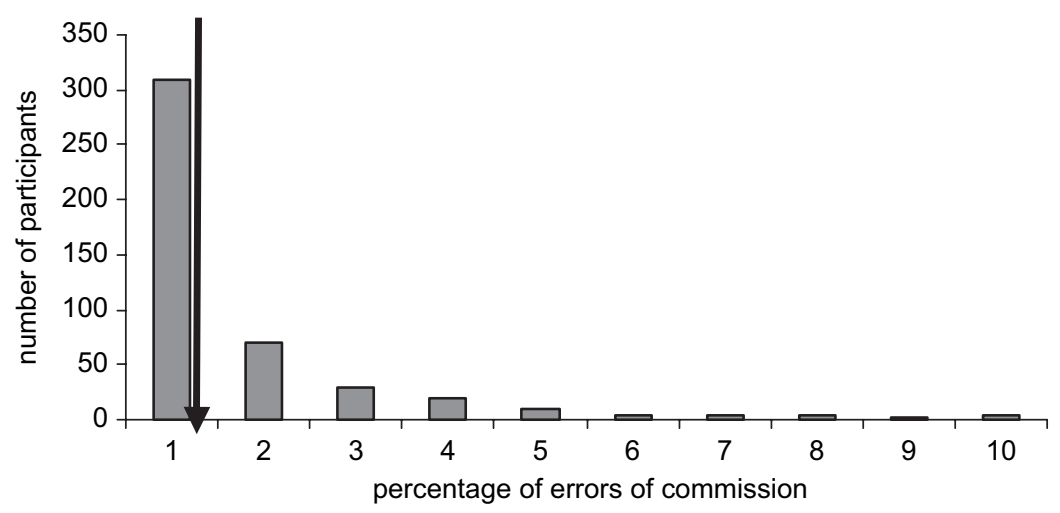

Figure 1B Distribution of impulsivity.

Note: Number of errors of commission divided by total number of items processed. The arrow indicates the borderline $(1 \%)$ between normal and weak performance. 
characterized by weak performance too small to enable meaningful prediction. For example, when the cutoff points were placed at $6.0 \%$ for inattention and $4.0 \%$ for impulsivity, only $6.2 \%$ respectively $4.7 \%$ of participants showed weak performance. Inattention and impulsivity were then analyzed by logistic regression analysis (normal $=0$, weak $=1$ ), using the same approach as described above. Alpha value was set at .05 for all analyses.

\section{RESULTS}

\section{Processing Speed}

Figure 2A shows the processing speed of children in the different grades. The linear regression model for processing speed was significant $(F[8,418]=38.20, p<.001$; $R^{2}=42.20 \%$ ). The total number of items processed increased significantly and linearly over the grades, with each grade performing better than the previous grade. Of the ageextrinsic variables studied, only one was significantly correlated with processing speed: "having more attention problems in daily life" was correlated with a slower performance. Specific grade differences and other statistics are reported in Table 2.

\section{Inattention}

Figure $2 \mathrm{~B}$ shows the proportion of children per grade who made more inattentive errors than the $3.0 \%$ cutoff point. The logistic regression model for inattention was not significant (Chi-square $=8.80, \mathrm{df}=4, p=.066$ ). To control whether the relation between grade and inattention was underestimated because inattention was dichotomized, we conducted a Spearman correlation analysis (nonparametric). Results showed a significant association with a small effect size $(\rho=-.11, p=.002)$ that did not change the implications of the above described results (J. Cohen, 1992).

\section{Impulsivity}

Figure $2 \mathrm{~B}$ also shows the proportion of children per grade who made more impulsive errors than the $1 \%$ cutoff point. The logistic regression models for impulsivity were significant (Chi-square $=74.38, p<.001)$. All group differences were found to be significant, except those between grades 4,5 , and 6 (see Table 2). In other words, impulsivity

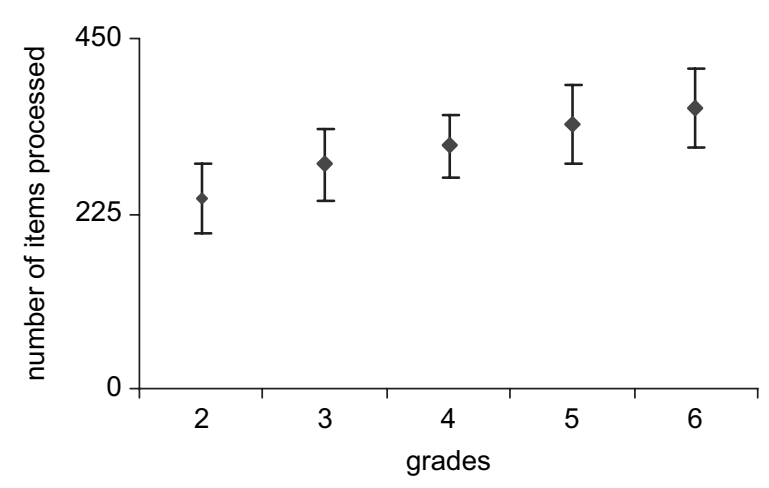

Figure 2A Processing speed over the grades. 


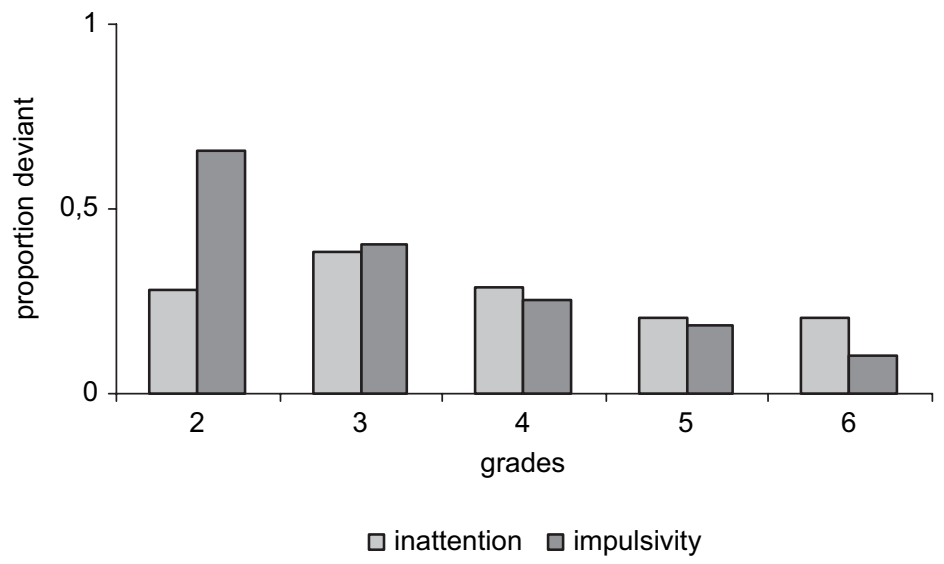

Figure 2B Inattention and impulsivity over the grades.

Table 2 Regression Models for Processing Speed and Inhibitory Control.

\begin{tabular}{|c|c|c|c|c|c|c|c|c|}
\hline \multirow[b]{2}{*}{ Differences } & \multicolumn{4}{|c|}{ Processing speed } & \multicolumn{4}{|c|}{ Inhibitory control } \\
\hline & $B$ & $S E$ & $\beta$ & $P$ value & $B$ & $S E$ & OR & $P$ value \\
\hline $2^{\text {nd }}<3^{\text {rd }}$ grade & 45.56 & 7.92 & .30 & .000 & -.99 & .36 & .37 & .006 \\
\hline $2^{\text {nd }}<4^{\text {th }}$ grade & 70.85 & 8.58 & .48 & .000 & -1.70 & .42 & .18 & .000 \\
\hline $2^{\text {nd }}<5^{\text {th }}$ grade & 95.82 & 10.04 & .64 & .000 & -1.82 & .51 & .16 & .000 \\
\hline $2^{\text {nd }}<6^{\text {th }}$ grade & 117.84 & 10.80 & .76 & .000 & -2.52 & .59 & .08 & .000 \\
\hline $3^{\text {rd }}<4^{\text {th }}$ grade & 25.29 & 7.24 & .17 & .001 & -.71 & .35 & .49 & .040 \\
\hline $3^{\text {rd }}<5^{\text {th }}$ grade & 50.26 & 8.20 & .33 & .000 & -.83 & .41 & .44 & .045 \\
\hline $3^{\text {rd }}<6^{\text {th }}$ grade & 72.28 & 8.78 & .47 & .000 & -1.53 & .50 & .22 & .002 \\
\hline $4^{\text {th }}<5^{\text {th }}$ grade & 24.97 & 7.31 & .17 & .000 & -.12 & .40 & .89 & .766 \\
\hline $4^{\text {th }}<6^{\text {th }}$ grade & 46.99 & 7.77 & .30 & .001 & -.82 & .48 & .44 & .087 \\
\hline $5^{\text {th }}<6^{\text {th }}$ grade & 22.02 & 7.24 & .14 & .002 & -.70 & .47 & .20 & .138 \\
\hline Sex & 6.36 & 4.61 & .05 & .168 & .35 & .24 & 1.41 & .154 \\
\hline EVA & -.21 & .60 & -.02 & .726 & -.04 & .03 & .96 & .194 \\
\hline LPE & -5.31 & 4.82 & -.04 & .271 & .39 & .25 & 1.48 & .109 \\
\hline $\mathrm{AT}$ & -2.82 & 1.05 & -.10 & .008 & .13 & .05 & 1.14 & .009 \\
\hline
\end{tabular}

Note. $B=$ Unstandardized regression coefficient, $S E=$ Standard error, $\beta=$ Standardized regression coefficient, $\mathrm{OR}=$ Odds ratio, EVA = Estimate of Verbal Ability, raw score on the Vocabulary subtest of the RAKIT (Bleichrodt et al., 1987; Evers et al., 2000); LPE = Level of Parental Education, scored on a 3-point scale ranging from 1 (low) to 3 (high), (Directoraat-Generaal voor de Arbeidsvoorziening, 1989); AT = raw score on the attention problems subscale of the CBCL (Achenbach, 1991; Verhulst et al., 1996).

appeared to be optimal in the fourth grade. Of the age-extrinsic variables studied, only the level of attention problems in daily life was correlated with impulsivity: children who were highly impulsive had more attention problems in daily life. To control whether the relation between grade and inattention was underestimated because impulsivity was dichotomized, we conducted a Spearman correlation analysis (nonparametric). Results showed a significant association with a medium effect size $(\rho=-.44, p<.001)$ that did not change the implications of the above described results (J. Cohen, 1992). 


\section{DISCUSSION}

We investigated processing speed, inattention, and impulsivity in a large population of Dutch schoolchildren in grades 2 to 6, using the d2Test of Attention. These three processes are regarded as aspects of selective attention (Brickenkamp \& Zillmer, 1998; Klimkeit et al., 2004; Manly et al., 2001). In addition, we controlled for several variables that may alter the development of selective attention, namely attention problems in daily life as reported by the parents, parental level of education, and verbal ability, as an estimate of intelligence. Most importantly, the results of this study indicated a differential development of the three aspects of selective attention. More specifically, no age-related improvement was found for level of inattention, indicating complete development in or before the second grade, level of impulsivity had stabilized in the fourth grade, and processing speed continued to improve into the sixth grade. These findings could be interpreted in light of Peter Anderson's model (2002) on the development of executive functioning. Executive function is an umbrella term for various processes that are responsible for purposeful, goal-directed behavior (P. Anderson, 2002; Lezak et al., 2004). In his model, based on cognitive and neuroimaging studies, Anderson proposes four executive domains that follow different developmental trajectories. Simple aspects of executive functioning develop before more complex ones. Inattention and impulsivity are regarded as part of the Attentional Control domain that develops fastest and is relatively mature by 9 years. Processing speed, on the other hand, is part of the Information Processing domain that is relatively mature by 12 years of age, but not completely established until midadolescence or early adulthood (P. Anderson, 2002). Based on this model, one would expect that processing speeds develop longer than inattention and impulsivity, consistent with our results. Thus, our findings are strong support for a step-wise model of cognitive development (V. A. Anderson, Anderson, Northam, Jacobs, \& Catroppa, 2001; Casey, Tottenham, Liston, \& Durston, 2005; De Bellis et al., 2001; Eslinger, Flaherty-Craig, \& Benton, 2004; Gogtay, Giedd, \& Rapoport, 2002; Gogtay, Giedd, Lusk, et al., 2004; Klingberg et al., 1999; Paus, 2005; Sowell \& Jernigan, 1998; Steinberg, 2005; Thatcher, 1991).

With regard to processing speed, we found an improvement into the sixth grade (age 12 years). Differences in processing speed decreased gradually over the grades, but remained significant. In other words, we did not find a plateau in performance after the fourth grade (age 10 years), as was expected. This finding is interesting in light of previous studies reporting that processing speed is already optimal by the age of 7 (McKay et al., 1994) or 10 years (Brodeur \& Pond, 2001; Klimkeit et al., 2004). This discrepancy could be due to the use of different selective attention tasks in which the number and nature of the distracters and the duration of the task varied from study to study, and to differences in sample size. Most importantly, the above mentioned studies all used experimental computerized paradigms whereas we employed a neuropsychological paper-and-pencil approach. Our results are more consistent with those of Hale (1990) and Kail (1991, 1996, 2000), who investigated processing speed not within a selective attention paradigm but as a separate cognitive function using reaction time tests. They showed that the reaction times of children and adolescents continued to decrease until the age of about 15 , when adult levels were reached. This prolonged development of processing speed has been explained by neural processes such as myelinization and synaptogenesis (Kail, 1996; Travis, 1998). We conclude that processing speed of selective attention continues to develop for longer than previously thought to be the case. 
Age-extrinsic variables are of importance when studying cognitive development because they can explain interindividual variance. We controlled for three such factors in our analyses of age differences in selective attention, namely, attention problems in daily life, parental level of education, and level of verbal ability. Attention problems in daily life, as reported by the parents on the CBCL (Achenbach, 1991; Verhulst et al., 1996), were correlated with processing speed and impulsivity. This confirms the ecological validity of the $\mathrm{d} 2$ Test of Attention. The results clearly showed that children with more attention problems in daily life performed slower and made more impulsive errors. Although these results may seem intuitive, they are contradictory to findings in children with ADHD. These children show clinical levels of attention problems in daily life, but they have been found to perform normally on tasks of selective attention (Booth et al., 2005; Hooks, Milich, \& Lorch, 1994; Huang-Pollock, Nigg, \& Carr, 2005; Manly et al., 2001). The sustained attention component of the task used might be associated with this contradiction: longer tasks have a stronger sustained attention component, and sustained attention is known to be compromised in ADHD (Manly et al., 2001). However, this appears not to be the case, because the duration of the $\mathrm{d} 2$ Test ( 4 minutes and 40 seconds) falls between Manly and colleagues' tasks (2001; 1 minute to 84 seconds) and Huang-Pollock and colleagues' task (2005; 20 minutes).

As Baron (2004) stated, "the minimal length required for a test to elicit failure to sustain attention is still debated" (p. 223). Although selective attention tasks are always shorter than classic vigilance tests, they are not consistently shorter than sustained attention tasks. Rather, their duration overlaps considerably in the child ADHD literature: sustained attention tests take as little as 3 minutes to as long as 30 minutes, whereas selective attention tasks last somewhere between 1 and 20 minutes (Brodeur \& Pond, 2001; Corkum \& Siegel, 1993; Hooks et al., 1994; Manly et al., 2001). Thus, test duration is not the most important variable when it comes to distinguishing children with and without ADHD using a sustained attention task (Corkum \& Siegel, 1993). Rather, children with and without ADHD can be best differentiated with a task that the child must attend to consistently because of short stimulus exposure duration, relatively short interstimulus interval, and higher percentage of targets (Corkum \& Siegel, 1993; Hooks et al., 1994). The d2 Test of attention requires constant attending and responding to and has a high percentage of targets. This may explain the association we found between selective attention as measured by the $\mathrm{d} 2$ Test and subclinical attention problems in daily life in children attending regular education.

Parental level of education is a recognized mediator of cognitive development in general (Bradley \& Corwyn, 2002; Kalff, Kroes, Vles, Bosma, et al., 2001) but we did not find it to be correlated with selective attention. Although our sample size was more than large enough to find subtle influences, we may not have found an effect because the mean level of parental education was relatively high in our sample. In other words, there may have been too few children in our sample whose parents had a low level of educational attainment. With regard to verbal ability, we did not find an association to any aspect of selective attention measured with the $\mathrm{d} 2$ Test. In a previous study of 435 first- and secondgrade children, it was found that children with higher verbal intelligence performed better on tasks of selective attention with high, but not low, processing demands (Pascualvaca et al., 1997). More specifically, verbal intelligence did not influence performance on the standard version of a digit cancellation test but it was related to performance on the distracted version of this test. Thus, we can conclude that $\mathrm{d} 2$ Test performance is not related to verbal intelligence, possibly because of low processing demands. 
Cultural factors may be of influence on the measurement of attention, for what is considered to be abnormal in one culture may be more acceptable in another. This was confirmed in a recent review that found great variations among the prevalence rates of ADHD in countries worldwide, ranging from $2.2 \%$ to $17.8 \%$ (Skounti, Philalithis, \& Galanakis, 2007). This indicates that there could be a difference in the extent to which inattentive behavior is accepted in Dutch relative to, for example, American classrooms, which would reduce the generalizability of our results. However, we believe the influence of cultural factors was minimized because the $\mathrm{d} 2$ Test and the CBCL attention problems subscale we employed to measure attention are standardized and frequently used in several nationalities (Achenbach, 1991; Baron, 2004; Brickenkamp \& Zillmer, 1998; Culbertson \& Sari, 1997; Spreen \& Strauss, 1998).

The results of this study have to be considered in light of several limitations. First, inattention and impulsivity were dichotomized in normal and weak performance. The choice of these cutoff points was, to a certain extent, arbitrary. Second, the total number of items processed may be a less valid way to measure processing speed than, for example, reaction times. Both these limitations are related to the use of the $\mathrm{d} 2$ Test for selective attention. However, we felt that these limitations were outweighed by the advantages of the $\mathrm{d} 2$ Test compared to other selective attention tests, such as high reliability and validity, short administration time, and suitability for group-based approaches. Third, cross-sectional samples are obviously less suitable for developmental research than longitudinal samples. This underscores the need for large-scale longitudinal investigations in selective attention and other aspects of cognitive development. Fourth, the group-based investigation took place in the classroom. Such a typically noisy context might be problematic for the assessment of attention. We minimized these distractions by administering the $\mathrm{d} 2$ Test first so concentration was optimal and fatigue minimal, and by providing detailed explanation and practice before administering the test. In addition, two investigators were present in each classroom during administration; one focused on reporting the 20 seconds interval and the other walked around to help with potential problems. Fifth, because of the association between attention and learning challenges, it is unfortunate that we do not know whether any of the participants of this study had been retained in a grade because of poor scholastic progress or had been provided with remedial tutorial assistance (Baron, 2004; Cooley \& Morris, 1990; Tannock, 2003).

In summary, in a large cross-sectional study we found that inattention did not change between the second and sixth grade, impulsivity had stabilized by the fourth grade, and processing speed continued to improve into the sixth grade. These findings support a step-wise model of cognitive development (P. Anderson, 2002), by which simple aspects of a cognitive function develop before more abstract aspects. Our study emphasizes the importance of breaking attention down into its subcomponents so subtype differences can be identified. This will enable early and more optimal detection and remediation of attentional weaknesses and deficits.

\footnotetext{
Original manuscript received October 22, 2006 Revised manuscript accepted December 29, 2006 First published online March 12, 2007
}

\section{REFERENCES}

Achenbach, T. M. (1991). Manual for the Child Behavior Checklist/4-18 and 1991 Profile. Burlington: University of Vermont Department of Psychiatry.

Anderson, P. (2002). Assessment and development of executive function (EF) during childhood. Child Neuropsychology, 8, 71-82. 
Anderson, V. A., Anderson, P., Northam, E., Jacobs, R., \& Catroppa, C. (2001). Development of executive functions through late childhood and adolescence in an Australian sample. Developmental Neuropsychology, 20, 385-406.

Baron, I. S. (2004). Neuropsychological evaluation of the child. Oxford: University Press.

Bleichrodt, N., Drenth, P. J. D., Zaal, J. N., \& Resing, W. C. M. (1987). Handleiding bij de Revisie Amsterdamse Kinder Intelligentie Test [Revised Amsterdam Child Intelligence Test manual]. Lisse: Swets \& Zeitlinger BV.

Booth, J. R., Burman, D. D., Meyer, J. R., Lei, Z., Trommer, B. L., Davenport, N. D., Li, W., Parrish, T. B., Gitelman, D. R., \& Mesulam, M. M. (2005). Larger deficits in brain networks for response inhibition than for visual selective attention in attention deficit hyperactivity disorder (ADHD). Journal of Child Psychology and Psychiatry, 46, 94-111.

Bradley, R. H., \& Corwyn, R. F. (2002). Socioeconomic status and child development. Annual Review of Psychology, 53, 371-399.

Brickenkamp, R., \& Zillmer, E. (1998). The d2 Test of attention. First US Edition. Göttingen: Hogrefe \& Huber Publishers.

Brodeur, D. A., \& Pond, M. (2001). The development of selective attention in children with attention deficit hyperactivity disorder. Journal of Abnormal Child Psychology, 29, 229-239.

Casey, B. J., Tottenham, N., Liston, C., \& Durston, S. (2005). Imaging the developing brain: What have we learned about cognitive development? TRENDS in Cognitive Sciences, 9, 104-110.

Cohen, J. (1992). A power primer. Psychological Bulletin, 112, 155-159.

Cohen, R. A. (1993). The neuropsychology of attention. New York: Plenum Press.

Cooley, E. L., \& Morris, R. D. (1990). Attention in children: A neuropsychologically based model for assessment. Developmental Neuropsychology, 6, 239-274.

Corkum, P. V., \& Siegel, L. S. (1993). Is the Continuous Performance Task a valuable research tool for use with children with Attention-Deficit-Hyperactivity Disorder? Journal of Child Psychology and Psychiatry, 34, 1217-1239.

Culbertson, W. C., \& Sari, D. (1997). A preliminary normative study of the d2 Test with American children. Archives of Clinical Neuropsychology, 4, 303-304.

Culbertson, W. C., \& Zillmer, E. A. (1998). The construct validity of the Tower of London DX as a measure of the executive functioning of ADHD children. Assessment, 5, 215-226.

De Bellis, M. D., Keshevan, M. S., Beers, S. R., Hall, J., Frustaci, K., Maselehdan, A., Noll, J., \& Boring, A. M. (2001). Sex differences in brain maturation during childhood and adolescence. Cerebral Cortex, 11, 552-557.

Directoraat-Generaal voor de Arbeidsvoorziening (1989). Handleiding voor de functieanalyse [Function analysis manual]. Den Haag: SDU uitgeverij.

Drechsler, R., Brandeis, D., Földényi, M., Imhof, K., \& Steinhausen, H-C. (2005). The course of neuropsychological functions in children with attention deficit hyperactivity disorder from late childhood to early adolescence. Journal of Child Psychology and Psychiatry, 46, 824-836.

Dunn, L. M., Dunn, L. M., Robertson, G. J., \& Eisenberg, J. L. (1979). Peabody Picture Vocabulary Test-Revised. Circle Pines, MN: American Guidance Service.

Eser, K. H. (1987). Reliabilitäts- und Validitätsaspekte des Aufmerksamkeits-Belastungs-Tests (Test d2) bei verhaltensgestörten Kindern und Jugendlichten. [Reliability and validity aspects of the $\mathrm{d} 2$ Test of Attention among children and adolescents with behavior problems.]. Diagnostica, 33, 74-80.

Eslinger, P. J., Flaherty-Craig, C. V., \& Benton, A. L. (2004). Developmental outcomes after early prefrontal cortex damage. Brain and Cognition, 55, 84-103.

Evers, A., van Vliet-Mulder, J. C., \& Groot, C. J. (2000). Documentatie van tests en test research in Nederland [Documentation of tests and test research in the Netherlands]. Assen: van Gordum; Amsterdam: Nederlands Instituut van Psychologen.

Fuchs, T., Birbaumer, N., Lutzenberger, W., Gruzelier, J. H., \& Kaiser, J. (2003). Neurofeedback treatment for attention-deficit/hyperactivity disorder in children: A comparison with methylphenidate. Applied Psychophysiology and Biofeedback, 28, 1-12. 
Gogtay, N., Giedd, J. N., Lusk, L., Hayaski, K. M., Greenstein, D., Vaituzis, A. C., Nugent, T. F. $3^{\text {rd }}$, Herman, D. H., Clasen, L. S., Toga, A. W., Rapoport, J. L., \& Thompson, P. M. (2004). Dynamic mapping of human cortical development during childhood through early adulthood. Proceedings of the National Academy of the Sciences, 101, 8174-8179.

Gogtay, N., Giedd, J., \& Rapoport, J. L. (2002). Brain development in healthy, hyperactive, and psychotic children. Archives of Neurology, 59, 1244-1248.

Hale, S. (1990). A global developmental trend in cognitive processing speed. Child Development, 61, 653-663.

Hooks, K., Milich, R., \& Lorch, E. P. (1994). Sustained and selective attention in boys with Attention Deficit Hyperactivity Disorder. Journal of Clinical Child Psychology, 23, 69-77.

Huang-Pollock, C. L., Nigg, J. T., \& Carr, T. H. (2005). Deficient attention is hard to find: Applying the perceptual load model of selective attention to attention deficit hyperactivity disorder subtypes. Journal of Child Psychology and Psychiatry, 46, 1211-1218.

Jackson, A. P. (2003). The effects of family and neighborhood characteristics on the behavioral and cognitive development of poor black children: A longitudinal study. American Journal of Community Psychology, 32, 175-186.

Kail, R. (1991). Developmental change in speed of processing during childhood and adolescence. Psychological Bulletin, 109, 490-501.

Kail, R. (1996). Nature and consequences of developmental change in speed of processing. Swiss Journal of Psychology, 55, 133-138.

Kail, R. (2000). Speed of information processing: Developmental change and links to intelligence. Journal of School Psychology, 38, 51-61.

Kalff, A. C., Kroes, M., Vles, J. S. H., Bosma, H., Feron, F. J. M., Hendriksen, J. G. M., Steyaert, J., van Zeben, T. M. C. B., Crolla, I. F. A. M., \& Jolles, J. (2001). Factors affecting the relation between parental education as well as occupation and problem behavior in Dutch 5- to 6- yearold children. Social Psychiatry and Psychiatric Epidemiology, 36, 324-331.

Kalff, A. C., Kroes, M., Vles, J. S. H., Hendriksen, J. G. M., Feron, F. J. M., Steyaert, J., van Zeben, T. M. C. B., Jolles, J., \& van Os, J. (2001). Neighborhood-level and individual-level SES effects on child problem behavior: A multilevel analysis. Journal of Epidemiology and Community Health, 55, 246-250.

Klemm, S., Schmidt, B., Knappe, S., \& Blanz, B. (2006). Impaired working speed and executive functions as frontal lobe dysfunctions in young first-degree relatives of schizophrenic patients. European Child \& Adolescent Psychiatry, 15, 400-408.

Klenberg, L., Korkman, M., \& Lahti-Nuuttila, P. (2001). Differential development of attention and executive functions in 3- to 12-year-old Finnish children. Developmental Neuropsychology, 20, 407-428.

Klimkeit, E. I., Mattingley, J. B., Sheppard, D. M., Farrow, M., \& Bradshaw, J. L. (2004). Examining the development of attention and executive functions in children with a novel paradigm. Child Neuropsychology, 10, 201-211.

Klingberg, T., Vaidya, C. J., Gabrieli, J. D. E., Moseley, M. E., \& Hedehus, M. (1999).Myelination and organization of the frontal white matter in children: A diffusion tensor MRI study. NeuroReport, 10, 2817-2821.

Kroes, M., Kalff, A. C., Kessels, A. G., Steyaert, J., Feron, F. J., van Someren, A. J., Hurks, P. P., Hendriksen, J. G., van Zeben, T. M., Rozendaal, N., Crolla, I. F., Troost, J., Jolles, J., \& Vles, J. S. (2001). Child psychiatric diagnoses in a population of Dutch schoolchildren aged 6 to 8 years. Journal of the American Academy of Child and Adolescent Psychiatry, 40, 1401-1409.

Langer, T., Martus, P., Ottensmeier, H., Hertzberg, H., Beck, J. D., \& Meier, W. (2002). CNS lateeffects after ALL therapy in childhood. Part III: Neuropsychological performance in long-term survivors of childhood ALL: Impairments of concentration, attention, and memory. Medical and Pediatric Oncology, 38, 320-328.

Lendt, M., Helmstaedter, C., \& Elger, C. E. (1999). Pre- and postoperative neuropsychological profiles in children and adolescents with temporal lobe epilepsy. Epilepsia, 40, 1543-1550. 
Lezak, M. D., Howieson, D. B., \& Loring, D. W. (2004). Neuropsychological assessment. New York: Oxford University Press.

Lin, C. C., Hsiao, C. K., \& Chen, W. J. (1999). Development of sustained attention assessed using the continuous performance test among children 6-15 years of age. Journal of Abnormal Child Psychology, 27, 403-412.

Lufi, D. (2001). Double-coding test: A new paper-and-pencil measure of eye-hand coordination. Perceptual and Motor Skills, 92, 815-826.

Manly, T., Anderson, V., Nimmo-Smith, I., Turner, A., Watson, P., \& Robertson, I. H. (2001). The differential assessment of children's attention: The Test of Everyday Attention for Children (TEA-Ch), normative sample and ADHD performance. Journal of Child Psychology and Psychiatry, 42, 1065-1081.

Marakovitz, S. E., \& Campbell, S. B. (1998). Inattention, impulsivity, and hyperactivity from preschool to school age: Performance of hard-to-manage boys on laboratory measures. Journal of Child Psychology and Psychiatry, 39, 841-851.

McKay, K. E., Halperin, J. M., Schwartz, S. T., \& Sharma, V. (1994). Developmental analysis of three aspects of information processing: Sustained attention, selective attention, and response organization. Developmental Neuropsychology, 10, 121-132.

Muller, S. V., Johannes, S., Wieringa, B., Weber, A., Muller-Vahl, K., Matzke, M., Kolbe, H., Dengler, R., \& Munte, T. F. (2003). Disturbed monitoring and response inhibition in patients with Gilles de la Tourette syndrome and co-morbid obsessive compulsive disorder. Behavioural Neurology, 14, 29-37.

Olvera, R. L., Semrud-Clikeman, M., Pliszka, S. R., \& O’Donnell, L. (2005). Neuropsychological deficits in adolescents with conduct disorder and comorbid bipolar disorder: A pilot study. Bipolar Disorders, 7, 57-67.

Pascualvaca, D. M., Anthony, B. J., Arnold, L. E., Rebok, G. W., Ahearn, M. B., Kellam, S. G., \& Mirsky, A. F. (1997). Attention performance in an epidemiological sample of urban children: The role of gender and verbal intelligence. Child Neuropsychology, 3, 13-12.

Paus, T. (2005). Mapping brain maturation and cognitive development during adolescence. TRENDS in Cognitive Sciences, 9, 60-67.

Penkman, L. (2004). Remediation of attention deficits in children: A focus on childhood cancer, traumatic brain injury and attention deficit disorder. Pediatric Rehabilitation, 7, 111-123.

Rebok, G. W., Smith, C. B., Pascualvaca, D. M., Mirsky, A. F., Anthony, B. J., \& Kellam, S. G. (1997). Developmental changes in attentional performance in urban children from eight to thirteen years. Child Neuropsychology, 3, 28-46.

Reimann, F. M., Samson, U., Derad, I., Fuchs, M., Schiefer, B., \& Stange, E. F. (2000). Synergistic sedation with low-dose midazolam and propofol for colonoscopies. Endoscopy, 32, 239-244.

Ruff, H. A., \& Lawson, K. R. (1990). Development of sustained, focused attention in young children during free play. Developmental Psychology, 26, 85-93.

Schreiber, H., Stolz-Born, G., Heinrich, H., Kornhuber, H. H., \& Born, J. (1992). Attention, cognition, and motor perseveration in adolescents at genetic risk for schizophrenia and control subjects. Psychiatry Research, 44, 125-140.

Seidl, R., Peyrl, A., Nicham, R., \& Hauser, E. (2000). A taurine and caffeine-containing drink stimulates cognitive performance and well-being. Amino Acids, 19, 635-642.

Skounti, M., Philalithis, A., \& Galanakis, E. (2007). Variations in prevalence of attention deficit hyperactivity disorder worldwide. European Journal of Pediatrics, 166, 117-123.

Smith, E. E., \& Jonides, J. (1999). Storage and executive processes in the frontal lobes. Science, 283, $1657-1661$.

Sowell, E. R., \& Jernigan, T. L. (1998). Further MRI evidence of late brain maturation: Limbic volume increases and changing asymmetries during childhood and adolescence. Developmental Neuropsychology, 14, 599-617.

Spreen, O., \& Strauss, E. (1998). A compendium of neuropsychological tests. New York: Oxford University Press. 
Stahl, L., \& Pry, R. (2005). Attentional flexibility and perseveration: Developmental aspects in young children. Child Neuropsychology, 11, 175-189.

Steinberg, L. (2005). Cognitive and affective development in adolescence. TRENDS in Cognitive Sciences, 9, 69-74.

Tannock, R. (2003). Neuropsychology of attention disorders. In S. J. Segalowitz \& I. Rapin (Eds.), Child Neuropsychology, Part II ( $2^{\text {nd }}$ edition, vol 8, pp. 753-784). Amsterdam: Elsevier Science BV.

Thatcher, R. W. (1991). Maturation of the frontal lobes: Physiological evidence for staging. Developmental Neuropsychology, 7, 397-419.

Travis, F. (1998). Cortical and cognitive development in 4th, 8th and 12th grade students. The contribution of speed of processing and executive functioning to cognitive development. Biological Psychology, 48, 37-56.

Verhulst, F. C., van der Ende, J., \& Koot, H. M. (1996). Handleiding voor de CBCL (Child Behavior Checklist) 4-18 [Manual for the CBCL]. Rotterdam: Afdeling Kinder en jeugdpsychiatrie, Sophia Kinderziekenhuis /Academisch Ziekenhuis Rotterdam/ Erasmus Universiteit Rotterdam, the Netherlands.

Wassenberg, R., Hendriksen, J. G. M., Hurks, P. P. M., Feron, F. J. M., Keulers, E. H. H., Vles, J. S. H., \& Jolles, J. (2007). Development of different aspects of sense of time: Results of a crosssectional study. Manuscript submitted for publication.

Weglage, J., Pietsch, M., Denecke, J., Sprinz, A., Feldmann, R., Grenzebach, M., \& Ullrich, K. (1999). Regression of neuropsychological deficits in early-treated phenylketonurics during adolescence. Journal of Inherited Metabolic Disease, 22, 693-705.

Weglage, J., Pietsch, M., Funders, B., Koch, H. G., \& Ullrich, K. (1996). Deficits in selective and sustained attention processes in early treated children with phenylketonuria-Result of impaired frontal lobe functions? European Journal of Pediatrics, 155, 200-204.

Wienbruch, C., Paul, I., Bauer, S., \& Kivelitz, H. (2005). The influence of methylphenidate on the power spectrum of ADHD children - An MEG study. BioMedCentral Psychiatry, 5, 29. 